\title{
ANALISA KANDUNGAN LIMBAH CAIR TEMPE AIR REBUSAN DAN AIR RENDAMAN KEDELAI
} \section{${ }^{1,2}$ STIKES WIDYAGAMA HUSADA \\ Corresponding author: DEVITA SARI STIKES WIDYAGAMA HUSADA \\ Email: devita.sariok@gmail.com}

DEVITA SARI ${ }^{1}$,ANYTA RAHMAWATI ${ }^{2}$,

\section{Article Info:}

Dikirim: 12 Desember 2019

Ditinjau: 21 Januari 2020

Diterima: 9 April 2020

DOI:

\section{Abstract}

Improper management of liquid waste can cause water pollution that can directly or indirectly interfere with the health of living things around it. The process of making tempe in each stage on average uses water for washing, soaking and boiling soybeans, this means that quite a lot of liquid waste is produced. The purpose of this study was to analyze the liquid waste content of boiled tempe water and soybean marinade water to be utilized again by the community or tempe craftsmen. The sample used was tempe liquid waste boiled water and soybean soaking water in one tempe entrepreneur in Kampung Sanan, Malang City. The sample is then tested to see the BOD, COD, TSS, and TDS contents. It also tested the nutritional content of the liquid tempeh liquid water of boiled water and soy bath water, namely protein, carbohydrates, fats, water and ash. The results showed that the BOD, COD, TSS, and TDS in both tempe liquid waste exceeded the quality standard stipulated by the East Java Governor Regulation No. 72 of 2013 concerning Quality Standards for Wastewater for Industry and / or Other Business Activities. As for the content of protein, carbohydrates, and fat there is but not too high, this shows that the tempe liquid waste can be reused which is nata de soya or other products. Reuse of tempe liquid waste can reduce water pollution.

Keywords: Nata; Waste; Tempe

\begin{abstract}
Abstrak
Manajemen pengelolaan limbah cair yang tidak sesuai bisa menimbulkan pencemaran air, yang dapat mengganggu kesehatan makhluk hidup disekitarnya. Proses pembuatan tempe dalam setiap tahapannya rata-rata menggunakan air untuk pencucian,perendaman dan perebusan kedelai, hal ini berarti limbah cair yang dihasilkan cukup banyak. Penelitian ini bertujuan untuk menganalisa kandungan limbah cair tempe air rebusan dan air rendaman kedelai untuk bisa di manfaatkan kembali oleh masyarakat atau pengrajin tempe. Sampel yang digunakan adalah limbah cair tempe air rebusan dan air rendaman kedelai di salah satu pengusaha tempe di Kampung Sanan Kota Malang. Sampel tersebut kemudian dilakukan uji untuk melihat kandungan BOD, COD, TSS, dan TDS. Selain itu juga diuji kandungan nutrisi pada limbah cair tempe air rebusan dan air rendaman kedelai, yaitu protein, karbohidrat, lemak,air dan abu. Hasil penelitian menunjukan bahwa BOD, COD, TSS, dan TDS pada kedua limbah cair tempe melebihi baku mutu yang ditetapkan oleh Peraturan Gubernur Jawa Timur Nomor 72 Tahun 2013 tentang Baku Mutu Air Limbah Bagi Industri dan/atau Kegiatan Usaha Lainnya. Sedangkan untuk kandungan protein,karbohidrat, dan lemak ada tapi tidak terlalu tinggi, hal ini menunjukan bahwa limbah cair tempe tersebut dapat dimanfaatkan kembali yaitu menjadi nata de soya atau produk lainnya. Pemanfaatan kembali limbah cair tempe dapat mengurangi pencemaran air.
\end{abstract}

Kata Kunci: Nata; Limbah; Temp 


\section{PENDAHULUAN}

Air merupakan sumber daya alam yang sangat diperlukan untuk keberadaan manusia dan sistem ekologi. Meskipun alam semesta telah menyediakan air, tetapi air tawar yang tersedia hanya $3 \%$. Rata-rata $5 \%$ air tawar ekivalen dengan $0,15 \%$ dari seluruh perairan di dunia yang mudah diakses untuk tujuan yang bermanfaat. Selain itu air berfungsi sebagai sumber daya yang penting dalam menjalankan industri, yang sebagian besar akan berakhir sebagai air limbah industri. Dalam beberapa dekade terakhir, kegiatan anthropogenic yang terjadi dengan urbanisasi dan industrialisasi yang cepat telah menghasilkan tekanan ekologi terhadap lingkungan air yang secara langsung atau tidak langsung mempengaruhi kesehatan manusia (Aniyikaiye, Oluseyi dkk. 2019). Anthropogenic yaitu segala sesuatu yang berhubungan dengan aktivitas manusia dan berdampak pula pada kehidupan manusia itu sendiri dan lingkungan. Keberadaan ekosistem air sering menunjukan tingkat degradasi lingkungan yang berasal dari kegiatan anthropogenic. Industri merupakan salah satu sumber polusi.

Air limbah industri yang dihasilkan dan langsung dibuang ke saluran air adalah salah satu sumber utama polusi lingkungan yaitu pencemaran air. Pembuangan limbah secara langsung tanpa pengolahan akan mempengaruhi kualitas air. Kualitas air yang tidak sesuai standar mutu yang ditetapkan akan berdampak buruk terhadap manusia dan sistem ekologi. Pada umumnya limbah yang di hasilkan oleh industri pangan memiliki karakteristik yaitu mengandung sejumlah besar bahan organik yaitu protein, karbohidrat, lemak, padatan tersuspensi serta tinggi kandungan Biochemical Oxygen Demand (BOD) dan Chemical Oxygen Demand (COD) (Khedkar \& Singh, 2015)
Teknik pengelolaan limbah industri dapat diklasifikasikan kedalam tiga cara yaitu pengurangan sumber limbah melalui modifikasi pabrik pengolahan, proses pemulihan limbah, mendaur ulang atau pengolahan limbah untuk nilai tambah produk dan detoxification atau menetralkan komponen limbah yang tidak diingankan. Pengelolaan limbah yang sempurna akan membuat proses produksi lebih efisien dan pencemaran bisa dikurangi.

Kampung Sanan merupakan salah satu pusat kegiatan industri, yaitu sentra industri keripik tempe dan tempe di Kota Malang. Industri tempe di Sanan dalam sehari membutuhkan 30 ton kedelai untuk di olah menjadi tempe dan keripik tempe. Proses pembuatan terdiri dari pencucian, perendaman, perebusan, dan peragian. Dalam setiap proses itu pengrajin tempe membutuhkan air yang cukup banyak, tetapi sekaligus menghasilkan limbah cair yang banyak pula. Limbah cair yang dihasilkan berpotensi menimbulkan pencemaran air. Selain itu proses produksi tempe di kampung Sanan masih menggunakan peralatan sederhana. Proses pembuangan limbah juga dilakukan secara sederhana, yaitu dengan cara langsung dibuang ke saluran air dan bagi sebagian yang memiliki ternak (lembu) biasanya digunakan untuk minuman ternak. Studi pendahuluan yang dilakukan peneliti menunjukan bahwa tidak ada bau menyengat yang ditimbulkan oleh proses produksi tempe karena gorong-gorong di kampung Sanan ini tertutup rapat, hanya ada lubang sebesar $45 \mathrm{~cm}$. Ketika peneliti berdiri di atas lubang tersebut bisa dilihat ada endapan-endapan proses pembuatan tempe serta bau yang menyengat.

\section{METODE}

Parameter kualitas air BOD, COD, TSS dianalisis berdasarkan cara American Public Health Association (APHA) yaitu Standard Methods For the Examination Of Water and Waste Water,sedangkan untuk TDS dianalisa 
menggunakan alat GPS Aquameter. Metode soxhlet digunakan untuk menganalisa lemak. Metode Kjedahl digunakan untuk menganalisa kandungan protein dalam bahan, kadar protein yang ditentukan berdasarkan cara Kjeldahl ini sering disebut sebagai kadar protein kasar. Perhitungan karbohidrat dihitung dengan menggunakan metode by difference.

\section{HASIL DAN PEMBAHASAN}

Hasil uji limbah cair tempe akan dibandingkan dengan baku mutu PERGUB Jatim nomor 72 Tahun 2013 tentang Baku Mutu Air Limbah Bagi Industri dan/atau Kegiatan Usaha Lainnya. Dari hasil uji laboratorium limbah cair tempe air rebusan dan air rendaman kedelai (Tabel 1) yang dilakukan di STIKES Widyagama Husada di peroleh data bahwa kandungan BOD,COD,dan TSS melebihi baku mutu.

Tabel 1. Hasil Analisa Kandungan Limbah Cair Tempe Air Rebusan dan Air Rendaman Kedelai

\begin{tabular}{|c|c|c|c|c|}
\hline \multirow[t]{2}{*}{ Parameter } & \multirow[t]{2}{*}{ Satuan } & \multirow{2}{*}{$\begin{array}{l}\text { Baku } \\
\text { Mutu Air } \\
\text { Limbah } \\
\text { Industri }\end{array}$} & \multicolumn{2}{|c|}{ Limbah Cair Tempe } \\
\hline & & & $\begin{array}{l}\text { Air } \\
\text { Rebusan } \\
\text { Kedelai }\end{array}$ & $\begin{array}{l}\text { Air } \\
\text { Rendaman } \\
\text { Kedelai }\end{array}$ \\
\hline $\begin{array}{l}\text { BOD } \\
\text { (Biochemical } \\
\text { Oxygen Demand) }\end{array}$ & $\mathrm{Mg} / \mathrm{l}$ & 150 & 9763 & 3298 \\
\hline $\begin{array}{l}\text { COD (Chemical } \\
\text { Oxygen Demand) }\end{array}$ & $\mathrm{Mg} / \mathrm{l}$ & 300 & 1672 & 5892 \\
\hline $\begin{array}{lr}\text { TSS } & \text { (Total } \\
\text { Suspended Solid) }\end{array}$ & $\mathrm{Mg} / \mathrm{l}$ & 100 & 1894 & 2396 \\
\hline $\begin{array}{l}\text { TDS (Total } \\
\text { Dissolve Solid) }\end{array}$ & $\mathrm{Mg} / \mathrm{l}$ & 5000 & 5192 & 3815 \\
\hline $\mathrm{pH}$ & - & $6,0-9,0$ & 05,90 & 06,37 \\
\hline
\end{tabular}

Keterangan: huruf tebal menandakan bahwa kandungan limbah melebihi NAB

Perbedaan baku mutu dengan hasil pengukuran memiliki nilai yang sangat besar. Sedangkan pada TDS hasil pengukuran menunjukan bahwa nilai TDS masih dalam normal (dibawah baku mutu) untuk limbah air rendaman kedelai, dan sedikit melebihi baku mutu untuk limbah air rebusan kedelai. Nilai pH untuk kedua limbah cair tempe masih dalam batas normal yaitu berada diantara 6-9. Merujuk hasil uji tersebut diatas secara tidak langsung pembuangan limbah cair tempe ke sungai secara langsung tanpa pengolahan akan dapat menyebabkan pencemaran air, apalagi jika didalam satu kawasan tersebut terdiri dari ratusan pabrik tempe maka bisa dipastikan pencemaran akan terjadi.

Limbah dari proses pangan biasanya juga mengandung sejumlah besar bahan organik seperti protein, lemak, dan karbohidrat (Khedkar \& Singh, 2015). Pada tabel 2 dapat dilihat kandungan protein, karbohidrat,dan lemak berturut-turut pada limbah cair tempe air rebusan kedelai adalah 0,47 g, 4,06 g dan 0,04 g. Sedangkan pada air rendaman kedelai adalah $0,20 \mathrm{~g}, 1,47 \mathrm{~g}$, dan 0,02 g. Jika dilihat pada hasil tersebut diatas maka limbah air rebusan kedelai memiliki kandungan gizi lebih baik dari air rendaman.

Tabel 2. Nutri Facts Limbah Cair Tempe Air Rebusan Kedelai Parameter Nutrition Facts Informasi Nilai Gizi Serving Size/Takaran $: 100 \mathrm{~g}$

\begin{tabular}{lll} 
& \multicolumn{2}{l}{ Saji } \\
\cline { 2 - 3 } & Calories/Kalori & $: 96 \mathrm{kkal}$ \\
\cline { 2 - 3 } & Calories From Fat/Kal & $: 1 \mathrm{kkal}$ \\
\hline & Berat & $\% \mathrm{AKG}^{*}$ \\
\hline $\begin{array}{l}\text { Lemak Total/Total } \\
\text { Fat }\end{array}$ & $0,04 \mathrm{~g}$ & 0,06 \\
\hline Protein/ Protein & $0,47 \mathrm{~g}$ & \\
\hline $\begin{array}{l}\text { Karbohidrat Total/ } \\
\text { Total Carbohydrate }\end{array}$ & $4,06 \mathrm{~g}$ & 0,94 \\
\hline Air/Moisture & $94,55 \mathrm{~g}$ & 1,35 \\
\hline Abu/Ash & $0,88 \mathrm{~g}$ & - \\
\hline
\end{tabular}

\section{PEMBAHASAN}

Hasil penelitian pada tabel 1 menunjukan bahwa nilai BOD, COD, dan TSS melebihi baku mutu pada PERGUB Jatim nomor 72 Tahun 2013 tentang Baku Mutu Air Limbah Bagi Industri dan/atau Kegiatan Usaha Lainnya. Biochemical Oxygen Demand (BOD) digunakan untuk mengukur beban limbah. BOD juga digunakan untuk menentukan dampak pembuangan pada air. BOD mengukur jumlah oksigen yang dikonsumsi oleh mikroorganisme dalam zat organik yang terurai di dalam air. Tingkat konsumsi oksigen dalam air dipengaruhi oleh 
sejumlah variabel yaitu temperatur, $\mathrm{pH}$, kehadiran beberapa jenis mikroorganisme, dan jenis organik serta inorganik di dalam air. BOD langsung mempengaruhi jumlah oksigen terlarut dalam aliran sungai. Semakin besar jumlah BOD, semakin cepat oksigen habis di dalam air. Ini berarti lebih sedikit oksigen yang tersedia bagi ekosistem air.

Chemical Oxygen Demand (COD) adalah pengukuran oksigen yang diperlukan untuk mengoksidasi zat organik yang larut dan partikulat dalam air. COD dapat diukur secara real time untuk meningkatkan pengendalian dan efisiensi proses pengolahan air limbah. Sama halnya dengan BOD, COD merupakan salah satu parameter penting dalam pengukuran kualitas air. Semakin tinggi COD berarti lebih banyak bahan organik teroksidasi dalam sampel, yang akan mengurangi kadar oksigen terlarut.

Konsekuensi dari tingginya BOD dan COD pada air bisa menyebabkan organisme menjadi stress, tercekik dan mati (Hur \& Cho, 2012)

Pada tabel 1 menunjukan bahwa bukan hanya BOD dan COD sebagai parameter kualitas air, tetapi keberadaannya adalah bersama-sama dengan parameter-parameter yang lain (Atima, 2015). Selain BOD dan COD terdapat parameter TSS (Total Suspended Solids) yang melebihi nilai ambang batas (NAB) pada kedua limbah cair tempe. Total Dissolve Solids (TDS) atau padatan terlarut pada limbah cair tempe melebihi sedikit NAB yaitu $5192 \mathrm{Mg} / \mathrm{l}$ pada limbah air rebusan kedelai dengan NAB adalah 5000 $\mathrm{Mg} / \mathrm{l}$. TSS dan TDS sangat beragam tergantung pada sifat kimia alamiah bahan tersuspensi tersebut.

TSS adalah padatan pada larutan tetapi tidak terlarut yang dapat mengakibatkan larutan menjadi keruh, dan tidak dapat langsung mengendap pada dasar lautan. Tanah liat,logam oksida,sulfida,ganggang,lumpur, jamur dan bakteri adalah termasuk zat padat tersuspensi. Kandungan partikel koloid pada TSS menyebabkan kekeruhan pada suatu larutan yang disebabkan oleh penyimpangan sinar yang menembus suspensi tersebut. Konsentrasi TSS dan temperatur air secara signifikan mempengaruhi kehidupan ikan di sungai (Nyanti et al., 2018).

Penyebab terbentuknya TDS adalah adanya bahan-bahan anorganik berupa ion-ion pada perairan. Dalam air alami komponen utama padatan terlarut adalah $\mathrm{Na}+, \mathrm{K}+, \mathrm{Ca} 2+$, Mg2+, Cl, SO42-, PO43-, H4SiO42-, dan HCO3. Air yang mengandung padatan terlarut berlebihan secara umum tidak sesuai untuk digunakan (Uddin, Alam, Mobin, \& Miah, 2015). Penelitian yang dilakukan Duffy (2014) menyebutkan bahwa efek TDS yang berlebihan menyebabkan berkurangnya tingkat kehamilan dan keterlambatan menetas pada ikan salmon. Disertai dengan dampak jangka panjang pada pertumbuhan dan perkembangannya. Perubahan temperatur, TDS, dan TSS pada sungai dan aliran air berpengaruh terhadap tingkat perkembangan dan kelangsungan hidup spesies yang berada di sungai (Mueller et al., 2017)

Sanan merupakan pusat industri keripik tempe dan tempe di Kota Malang, dimana ratusan home industri pembuatan tempe ada disini. Di Sanan dalam satu hari dibutuhkan 30 ton kedelai untuk dibuat tempe, dan dalam proses pembuatan tempe banyak menggunakan air. Oleh karena itu bisa diperkirakan berapa ratus liter pembuangan limbah cair tempe ke selokan yang akan mengalir ke sungai.

Para pemilik home industri tempe selama ini tidak pernah melakukan pengelolaan limbah cair tempe. Limbah dari proses pembuatan tempe termasuk dalam limbah biodegradable yaitu limbah atau limbah material yang dapat dihancurkan oleh mikroorganisme. Senyawa organik yang terkandung di dalamnya akan dihancurkan oleh bakteri saat prosesnya semakin lambat dan sering disertai dengan bau busuk. Dalam limbah domestik, sebagian besar nitrogen organik akan dikonversi menjadi amonia dalam peluruhan anaerob dan menjadi nitrat atau 
nitrit dalam dekomposisi aerobik (Sumantri \& Cordova, 2011). Oleh karena itu pembuangan limbah cair tempe ke selokan dan sungai tanpa pengelolaan akan mempengaruhi kualitas air. Kualitas air juga berpengaruh terhadap kesehatan, mengingat sifat air yang mudah sekali terkontaminasi oleh berbagai mikroorganisme dan mudah sekali melarutkan berbagai mineral. Kondisi sifat air tersebut menyebabkan air mudah sekali berfungsi sebagai media penyalur atau penyebar penyakit (Wibowo, 2013)

Tabel 3. Nutri Facts Limbah Cair Tempe Air Rendaman Kedelai

\begin{tabular}{lll}
\multirow{2}{*}{ Parameter } & \multicolumn{2}{l}{ Nutrition Facts Informasi Nilai Gizi } \\
\cline { 2 - 3 } & $\begin{array}{l}\text { Serving Size/Takaran } \\
\text { Saji }\end{array}$ & \\
& Calories/Kalori $\mathrm{g}$ \\
& Calories From Fat/Kal & $: 1 \mathrm{kkal}$ \\
\cline { 2 - 3 } & Berat & $\% \mathrm{AKG}^{*}$ \\
\hline Lemak Total/Total Fat & $0,04 \mathrm{~g}$ & 0,06 \\
\hline Protein/ Protein & $0,47 \mathrm{~g}$ & 0,94 \\
\hline Karbohidrat Total/ & $4,06 \mathrm{~g}$ & 1,35 \\
Total Carbohydrate & & \\
\hline Air/Moisture & $94,55 \mathrm{~g}$ & - \\
\hline Abu/Ash & $0,88 \mathrm{~g}$ & -
\end{tabular}

\section{KESIMPULAN}

Berdasarkan data dan hasil analisa dapat disimpulkan bahwa limbah cair tempe air rebusan dan air rendaman kedelai memiliki kandungan BOD,COD,TSS pada kedua limbah dan TDS pada limbah cair tempe air rebusan melebihi NAB, sedangkan kandungan TDS pada limbah cair air rendaman kedelai memiliki angka pada batas maksimal NAB yaitu $5000 \mathrm{Mg} / \mathrm{l}$. Kandungan BOD, COD,TSS, dan TDS berpengaruh pada kualitas air. Kualitas air yang buruk dapat menjadi sumber polutan kehidupan di air, dan secara langsung dan tidak langsung juga dapat mempengaruhi derajat kesehatan manusia.

Saran untuk penelitian lanjutan yaitu mengukur parameter kualitas air pada sungai disekitar industri sehingga bisa diketahui apakah terjadi pencemaran air. Sedangkan saran untuk masyarakat setempat dan pemerintah adalah untuk lebih memperhatikan pembuangan limbah cair tempe/limbah industri yang dilakukan tanpa adanya pengelolaan terlebih. Data kandungan limbah cair tempe dapat digunakan untuk pengelolaan limbah cair dengan memanfaatkan kembali menjadi produk kembali, misalnya adalah membuat nata de soya, biogas, dan pupuk dari limbah cair tempe tersebut

\section{DAFTAR RUJUKAN}

Aniyikaiye, T. E., Oluseyi, T., Odiyo, J. O., \& Edokpayi, J. N. (2019). Physico-chemical analysis of wastewater discharge from selected paint industries in Lagos, Nigeria. International Journal of Environmental Research and Public Health, 16(7). https://doi.org/10.3390/ijerph16071235

Atima, W. (2015). BOD dan COD Sebagai Parameter Pencemaran Air dan Baku Mutu Air Limbah. Jurnal Biology Science \& Education 2015, 4(1), 83-93.

Duffy, L. (2014). Effects of Total Dissolved Solids on Aquatic Organisms: A Review of Literature and Recommendation for Salmonid Species Effects of Total Dissolved Solids on Aquatic Organisms : A Review of Literature and Recommendation for Salmonid Species, (May). https://doi.org/10.3844/ajessp.2007.1.6

Hur, J., \& Cho, J. (2012). Prediction of BOD, COD, and total nitrogen concentrations in a typical urban river using a fluorescence excitation-emission matrix with PARAFAC and UV absorption indices. Sensors, $\quad$ 12(1), 972-986. https://doi.org/10.3390/s120100972

Khedkar, R., \& Singh, K. (2015). New Approaches for Food Industry Waste Utilization. ResearchGate, (January 2015), 51-65. Retrieved from https://www.researchgate.net/publication/3033418 20

Mueller, J. S., Grabowski, T. B., Brewer, S. K., Worthington, T. A., Mueller, J. S., \& Hall, A. 
(2017). Effects of Temperature, Total Dissolved Solids, and Total Suspended Solids on Survival and Development Rate of Larval Arkansas River Shiner. Journal of Fish and Wildlife Management, 8(1), 79-88. https://doi.org/10.3996/112015JFWM-111

Nyanti, L., Soo, C., Ling, T., Sim, S., Grinang, J., Ganyai, T., \& Lee, K. (2018). Effects of water temperature and $\mathrm{pH}$ on total suspended solids tolerance of Malaysian native and exotic fish species. AACL Bioflux, 11(3), 565-575.

Sumantri, A., \& Cordova, M. (2011). Dampak Limbah Domestik Perumahan Skala Kecil Terhadap Kualitas Air Ekosistem Penerimanya Dan Dampaknya Terhadap Kesehatan Masyarakat. JPSL, 1(2), 127-134.
Uddin, M., Alam, M., Mobin, M., \& Miah, M. (2015). An Assessment of the River Water Quality Parameters: A case of Jamuna River. Journal of Environmental Science and Natural Resources, $7(1)$ 249-256.

https://doi.org/10.3329/jesnr.v7i1.22179

Wibowo, S. B. (2013). Dampak Kualitas Perairan Hubungannya Terhadap Risiko Kesehatan Di Perairan Donan, Cilacap-Cilacap- Jawa Tengah (pp. 1-97).

Cite this article as: Sari D, Anyta R. (2020). Analisa Kandungan Limbah Cair Tempe Air Rebusan Dan Air Rendaman Kedelai Jurnal Ilmiah Media Husada. Vol 1(No 2), 36-41. https://doi.org/10.33475/jikmh.v9i1.210 